\begin{tabular}{l}
\hline 120 Of Management \\
Volume 1, Nomor 1, Juni 2020 \\
P-ISSN: 2722-4937, E-ISSN: 2722-4961 \\
Website: http: pasca-umi.ac.id/index.php/jms \\
This work is licensed under a Creative Commons Attribution 4.0 International License.
\end{tabular}

\title{
Analisis Pajak Daerah Kota Makassar
}

\section{Andi Wahyu Rasyid Azis, ${ }^{1,2}$ Baharuddin Semmaila ${ }^{1}$ \& Muchtar Lamo ${ }^{1}$}

${ }^{1}$ Magister Ilmu Ekonomi Universitas Muslim Indonesia

${ }^{2}$ Koresponden Penulis, E-mail: andiwahyu.azis@gmail.com

\begin{abstract}
ABSTRAK
Penelitian ini bertujuan untuk mengetahui kesesuaian jenis pajak Daerah Kota Makassar yang dipungut dengan undang-undang dan peraturan daerah, kontribusi jenis pajak dan efektivitas pajak daerah serta menganalisis dampak covid-19 terhadap pajak Daerah Kota Makassar. Metode pengumpulan data adalah dokumentasi, studi pustaka, wawancara dan pengamatan langsung. Metode analisis adalah analisis deskriptif kuantitatif dan kualitatif. Hasil penelitian ini adalah jenis pajak Daerah Kota Makassar yang dipungut sudah sesuai dengan undang-undang dan peraturan daerah. Jenis pajak penerangan jalan, BPHTB dan pajak restoran memberi kontribusi besar sedangkan pajak mineral bukan logam, pajak sarang burung walet dan pajak air bawah tanah memberi kontribusi yang kecil terhadap total pajak daerah Kota Makassar. Tingkat efektivitas penerimaan pajak daerah adalah cukup efektif. covid-19 berpengaruh negatif terhadap target dan realisasi pajak
\end{abstract}

Kata Kunci: Pajak; Daerah; Kontribusi;

\begin{abstract}
This study aims to determine the suitability of the types of Makassar City Regional taxes collected with local laws and regulations, the contribution of tax types and the effectiveness of local taxes and to analyze the impact of Covid-19 on Makassar City Regional taxes. Data collection methods are documentation, literature study, interviews and direct observation. The analysis method is descriptive quantitative and qualitative analysis. The results of this study are the types of Makassar City Regional taxes collected are in accordance with local laws and regulations. The types of street lighting tax, ВPHTB and restaurant taxes made a large contribution while non-metal mineral taxes, swallow's nest taxes and underground water taxes contributed small to the total local taxes of Makassar City. The level of effectiveness of local tax revenues is quite effective. covid-19 has a negative effect on tax targets and realization.
\end{abstract}

Keyword: Training; Vocational, professional transfer; Entrepreneur. 


\section{PENDAHULUAN}

Otonomi Daerah memberikan kewenangan dan tanggung jawab yang luas kepada pemerintah daerah untuk menyelenggarakan pemerintahan, pelayanan masyarakat dan pembangunan (Ristanti \& Handoyo, 2017). Penyelenggaraan pembangunan daerah sangat memerlukan sumber daya manusia yang berkualitas, ketersediaan sumber daya alam dan ketersediaan dana (Nasution, 2019).

Pembangunan daerah dalam nuansa otonomi saat ini telah membawa perubahan mendasar dari arah pembangunan yang sentralistik menjadi desentralisasi, yaitu adanya pemberian wewenang kepada daerah otonom yang mengatur dan mengembangkan segenap potensi yang dimiliki daerah (Winarno, 2004). Dengan demikian potensi daerah akan bisa tergarap secara optimal dan pelaksanaan pembangunan pun bisa mengenai sasaran sesuai dengan kebutuhan daerah. Dalam otonomi Daerah terkandung pula asas desentralisasi fiskal yang berarti bahwa pemerintah kabupaten atau kota diberikan hak dan wewenang untuk mengatur dan mengelola sumber-sumber penerimaan dan pengeluaran keuangan daerah secara efisien dan efektif (Mangeswuri, 2018).

Kinerja keuangan daerah sangat tergantung pada kemampuan ekonomi masyarakat dan tingkat pertumbuhan ekonomi (potensi ekonomi) yang dapat diciptakan oleh daerah adalah meningkatkan pertumbuhan ekonomi secara maksimal (Syamsudin, $e t, a l, 2015)$. Ini sangat tergantung pada potensi sumber daya alam, sumber daya manusia dan sumber daya keuangan yang dimiliki oleh daerah yang bersangkutan.

Di lain pihak, menurut Undang-Undang Nomor 32 Tahun 2004 tentang Pemerintahan Daerah dijelaskan mengenai eksistensi pelaksanaan otonomi daerah yang nyata dan bertanggung jawab, yaitu daerah diberi wewenang untuk melaksanakan berbagai urusan pemerintahan di dalam mengatur dan mengurus rumah tangganya sendiri, baik dalam hal pembiayaan rutin maupun pembiayaan pembangunan (Wijayanti, 2017).

Usaha untuk menggali sumber-sumber pendapatan daerah yang potensial tersebut dimaksudkan untuk menghimpun dan menyediakan dana sebesar-besarnya guna kebutuhan pembiayaan kegiatan pembangunan daerah (Arief \& Djanggih, 2020). Dengan demikian keberhasilan penyelenggaraan pemerintahan, pelayanan masyarakat dan kegiatan pembangunan di daerah sangat tergantung dari kemampuan keuangan masing-masing daerah.

Kemampuan keuangan daerah adalah kemampuan pengelolaan sumber-sumber penerimaan daerah guna membiayai pembangunan daerah. Objek pengelolaan keuangan daerah adalah sisi penerimaan dan sisi pengeluaran dalam anggaran pendapatan dan belanja daerah (Kamaroellah, 2017). Pada sisi penerimaan daerah, pemerintah dapat melakukan dua hal yaitu memobilisasi sumber-sumber penerimaan melalui intensifikasi dan ekstensifikasi serta berupaya untuk mengoptimalkan penerimaan yang berasal dari sumber-sumber penerimaan baru (Astuty, 2018). Sedangkan pada sisi pengeluaran, pemerintah daerah harus melakukan efisiensi anggaran.

Kota Makassar adalah merupakan pintu gerbang Kawasan Timur Indonesia yang memiliki posisi yang sangat strategis. Memperhatikan fenomena di lapangan 
menunjukkan bahwa terjadi pertumbuhan penduduk dan aktivitas perekonomian yang sangat tinggi. Jumlah penduduk Kota Makassar yang cenderung meningkat dari tahun ke tahun dan pertumbuhannya sangat tinggi yakni pada tahun 2010 sebanyak 1,2 juta dan pada tahun 2011 mencapai 1,5 juta jiwa, karena Makassar sebagai "Ruang Tamu" Kawasan Timur Indonesia (KTI), ramai dikunjungi dan menjadi alternatif untuk mencari penghidupan.

Sementara dari sisi pertumbuhan ekonomi, sejak 2018 mencapai di atas sembilan persen atau lebih tinggi dari persentase pertumbuhan ekonomi nasional. Bahkan angka pertumbuhan ekonomi Makassar sempat menembus 10,51 persen. Itu terjadi ketika pembangunan Bandara Internasional Sultan Hasanuddin, jalan tol dan mega proyek Trans Studio. Fenomena di atas menunjukkan bahwa harus ditunjang oleh perkembangan pembangunan di berbagai sektor. Untuk melaksanakan pembangunan tersebut, tentu membutuhkan anggaran yang cukup tinggi. Salah satu sumber pendapatan daerah adalah pajak daerah.

Kota Makassar, seperti halnya dengan daerah otonomi daerah lainnya di Indonesia merasakan bahwa sumber-sumber pendapatan asli daerah jumlahnya terbatas, sedangkan biaya yang dibutuhkan untuk membiayai tugas-tugas pemerintahan dan pembangunan daerah sangat banyak. Untuk mengatasi keterbatasan dana ini biasanya dibantu dari Pemerintah Pusat dan Pemerintah Provinsi Sulawesi Selatan.

Untuk mendukung pelaksanaan otonomi yang baik, pemerintah mengeluarkan kebijakan di bidang penerimaan daerah yang berorientasi pada peningkatan kemampuan daerah untuk membiayai urusan rumah tangganya sendiri dan diprioritaskan pada penggalian dana mobilisasi sumber-sumber daerah. Pendapatan Asli Daerah (PAD) merupakan sumber pendapatan daerah yang secara bebas dapat digunakan oleh masing-masing daerah untuk menyelenggarakan pemerintahan dan pembangunan daerah. Tapi pada kenyataannya kontribusi pendapatan asli daerah terhadap pendapatan dan belanja daerah masih kecil. Selama ini dominasi sumbangan pemerintah pusat kepada daerah masih besar. Oleh karenanya untuk mengurangi ketergantungan kepada pemerintah pusat, Pemerintah daerah perlu berusaha meningkatkan Pendapatan Asli Daerah (PAD). Pendapatan Asli Daerah bersumber dari pajak daerah, retribusi daerah, laba BUMD, dan Lain-lain pendapatan yang sah. Untuk itu, dibutuhkan anggaran pembangunan yang besar. Anggaran tersebut salah satunya bersumber dari Pendapatan Asli Daerah (PAD) dimana sumber PAD terbesar adalah dari pajak daerah. Salah satu sumber PAD yang harus dikelola dengan baik adalah pajak daerah.

Kota Makassar yang memiliki banyak sumber-sumber pajak daerah tentunya diharapkan penerimaan pajak daerah dikelola dengan baik dalam rangka meningkatkan pembangunan di Kota Makassar. Pengelolaan itu baik jika aturan, kebijakan, perencanaan dan pelaksanaannya baik. Terdapat berbagai masalah pajak yang perlu diketahui melalui penelitian.

Dalam UU No. 28 tahun 2009 sudah ditetapkan jenis pajak daerah Kabupaten/kota yang dapat dipungut yaitu:

a. Pajak Hotel;

b. Pajak Restoran;

c. Pajak Hiburan; 
d. Pajak Reklame;

e. Pajak Penerangan Jalan;

f. Pajak Mineral Bukan Logam dan Batuan

g. Pajak parkir

h. Pajak Air Tanah;

i. Pajak Sarang Burung Walet;

j. Pajak Bumi dan Bangunan Perdesaan dan Perkotaan;

k. Bea Perolehan Hak atas Tanah dan Bangunan

Daerah dilarang memungut pajak selain jenis pajak tersebut. Jenis pajak tersebut dapat tidak dipungut apabila potensinya kurang memadai dan/atau disesuaikan dengan kebijakan Daerah yang ditetapkan dengan Peraturan Daerah (Sidik, 2002). Sehubungan dengan itu, maka perlu dievaluasi kesesuaian antara jenis Pajak Daerah Kota Makassar yang dipungut dengan UU dan Peraturan daerah.

Dari 11 jenis pajak tersebut tentu memberi kontribusi yang bervariasi terhadap total pajak daerah. Perlu diketahui jenis pajak apa yang kontribusinya besar juga yang kontribusinya kecil terhadap total pajak daerah sebagai bahan pertimbangan dalam membuat kebijakan dan peraturan (Saragih, 2018). Perencanaan target pajak diperlukan sebagai tolak ukur target yang diharapkan dapat dicapai. Realisasi penerimaan pajak perlu dibandingkan dengan target pajak. Untuk itu perlu diketahui tingkat efektivitas penerimaan pajak daerah (Rahman, 2010).

Covid-19 terjadi pada awal tahun 2020 yang menyebabkan terjadinya pembatasan sosial (social distancing), pembatasan jarak fisik (phisical distancing) bahkan pembatasan sosial berskala besar (PSBB) di Kota Makassar. Pembatasan tersebut mulai terjadi secara bertahap pada bulan Maret 2020 dan berlangsung sampai sekarang. Pembatasan tersebut menyebabkan terjadinya penurunan aktivitas ekonomi yang tentunya perlu diketahui dampak (pengaruhnya) terhadap target dan realisasi penerimaan pajak daerah

\section{METODE PENELITIAN}

Penelitian ini dilaksanakan pada Pemerintah Kota Makassar. Waktu penelitian ini dilaksanakan pada bulan September-September 2020. Data yang digunakan dalam penelitian ini terdiri dari data primer dan sekunder. Data primer adalah data yang diambil langsung oleh peneliti di lapangan berupa data hasil wawancara dan pengamatan. Sedangkan data sekunder adalah data yang diperoleh dari dokumen yang sudah ada dari Pemerintah Kota Makassar yang berkaitan dengan pajak Daerah Kota Makassar dan data/dokumen yang ada di internet.

\section{Pengolahan Data dan Analisis Hasil}

Data yang didapatkan diolah dan dianalisis sebagai berikut:

\section{Kesesuaian jenis Pajak yang dipungut dengan undang-undang dan Peraturan Daerah Kota Makassar.}

Jenis pajak daerah Kota Makassar yang dipungut pada tahun 2019 dan 2020 dilihat kesesuaiannya dengan jenis pajak daerah Kabupaten/Kota dalam UU RI Nomor 28 
Tahun 2009 dan Jenis pajak daerah dalam Peraturan Daerah Kota Makassar Nomor 2 Tahun 2018.

\section{Analisis Kontribusi Jenis Pajak Daerah terhadap Total Pajak Daerah}

Besarnya kontribusi sumber pajak daerah terhadap total pajak daerah dihitung dengan menggunakan rumus sebagai berikut:

$$
K=\frac{J}{T_{n}} X 100 \%
$$

Keterangan:

$\mathrm{K}=$ Kontribusi jenis pajak daerah terhadap total pajak daerah

$\mathrm{J}=$ Jumlah penerimaan jenis pajak daerah

$\mathrm{T}=$ Total realisasi pajak daerah

Dari hasil perhitungan tersebut dianalisis yang kontribusinya besar dan yang kontribusinya kecil.

\section{Efektivitas Pajak Daerah}

Besarnya efektivitas penerimaan pajak daerah dihitung dengan menggunakan metode Charch Performan Index (CPI) dengan rumus (Devas, et al. (1999: 214), Syamsuddin dkk. (2015) dan Enggar dkk (2011) dapat dihitung dengan rumus sebagai berikut:

$$
\text { Efektivitas }=\frac{\text { Realisasi penerimaan pajak daerah }}{\text { Target penerimaan pajak daerah }} \times 100
$$

Hasil perhitungan tersebut dianalisis tingkat efektivitasnya dengan kategori:

Ukuran tingkat efektivitas dapat mengacu pada Kepmendagri No. 690.900.327 tahun 1996 yang intinya adalah sebagaimana pada tabel berikut ini.

Tabel 1 Kategori tingkat efektivitas

$\begin{array}{cc}\text { Nilai Efektivitas } & \text { Kategori } \\ >100 \% & \text { Sangat efektif } \\ 90-100 \% & \text { Efektif } \\ 80-90 \% & \text { Cukup efektif } \\ 60-80 \% & \text { Kurang efektif } \\ <60 \% & \text { Tidak efektif }\end{array}$

\section{HASIL PENELITIAN DAN PEMBAHASAN}

\section{Hasil}

\section{A. Kontribusi Jenis Pajak Daerah terhadap Total Pajak Daerah Kota Makassar}

Berdasarkan hasil pengolahan data kontribusi jenis pajak daerah terhadap total pajak Daerah Kota Makassar tahun 2019 dan 2020 pada lampiran 1, diperoleh hasil perhitungan kontribusi jenis pajak daerah terhadap jumlah pajak Daerah Kota Makassar tahun 2019 dan 2020 sebagaimana pada tabel berikut.

Tabel 1 Kontribusi jenis pajak daerah terhadap total pajak daerah 


\begin{tabular}{|c|c|c|c|c|c|}
\hline \multirow[b]{2}{*}{ No } & \multirow[b]{2}{*}{ Jenis pajak } & \multicolumn{2}{|c|}{$\begin{array}{l}\text { REALISASI s.d TGL } \\
\text { 30 SEPTEMBER } 2019 \\
\end{array}$} & \multicolumn{2}{|c|}{$\begin{array}{l}\text { REALISASI s.d TGL } 30 \\
\text { SEPTEMBER } 2020\end{array}$} \\
\hline & & Jumlah (Rp) & $\begin{array}{c}\text { Kontri } \\
\text { busi } \\
(\%)\end{array}$ & Jumlah (Rp) & $\begin{array}{c}\text { Kontri } \\
\text { busi } \\
(\%)\end{array}$ \\
\hline 1 & ВРНТВ & $134.120 .889,723$ & 40,64 & 117.485 .711 .742 & 57,31 \\
\hline 2 & PBB - P2 & $140.437 .677,002$ & 65,32 & 144.053 .699 .031 & 107,50 \\
\hline 3 & Pajak hotel & 79.953.473,895 & 59,22 & 34.410.476.734 & 47,79 \\
\hline 4 & Pajak hibura & $30.448 .418,759$ & 39,54 & 12.488.254.483 & 41,63 \\
\hline 5 & Pajak air bawah tanah & 2.633.356,094 & 37,62 & 3.106 .969 .508 & 102,33 \\
\hline 6 & Pajak restoran & $150.275 .011,671$ & 81,23 & 97.804.125.795 & 93,47 \\
\hline 7 & Pajak penerangan jalan & $163.829 .713,409$ & 65,53 & 165.173.276.465 & 79,03 \\
\hline 8 & Pajak parkir & $14.626 .399,020$ & 24,08 & 7.282.017.568 & 66,20 \\
\hline 9 & $\begin{array}{l}\text { Pajak mineral bukan } \\
\text { logam }\end{array}$ & 0 & 0 & 0 & 0 \\
\hline 10 & Pajak sarang burung walet & $18.228,400$ & 7,29 & 15.189 .800 & 60,76 \\
\hline 11 & Pajak reklame & $32.410 .723,626$ & 61,15 & 28.223.239.312 & 68,84 \\
\hline & Total & $748.753 .891,599$ & 100 & 610.042 .960 .438 & 100 \\
\hline
\end{tabular}

Sumber: Badan Pendapatan Daerah Kota Makassar tahun 2020 (diolah)

Data kontribusi yang perlu mendapatkan perhatian adalah yang memberikan kontribusi yang besar dan yang kecil. Dikatakan besar kalau kontribusinya besar dan jauh dari rata-rata, sebaliknya dikatakan kecil kalau kontribusinya kecil dan jauh dari rata-rata. Dari data tersebut, maka kontribusinya dikatakan besar jika $>19 \%$ dan kecil jika kontribusinya $<1 \%$. Dari hasil pengolahan data kontribusi didapatkan 4 jenis pajak yang memberikan kontribusi besar yaitu pajak penerangan jalan, BPHTB, pajak restoran serta PBB-P2. Ada 3 jenis pajak yang memberikan kontribusi kecil adalah pajak mineral bukan logam, pajak sarang burung walet dan pajak air bawah tanah.

\section{B. Efektivitas Penerimaan Pajak Daerah Kota Makassar}

Besarnya efektivitas pajak daerah dapat dihitung dengan rumus sebagai berikut: (Devas, 1989: 214), Syamsuddin dan Hamid (2014)

Efektivitas $=\frac{\text { Realisasi penerimaan pajak daerah }}{\text { Target penerimaan pajak daerah }} \times 100 \%$

Berdasarkan hasil pengolahan data efektivitas penerimaan pajak Daerah Kota Makassar tahun 2019 dan 2020 pada lampiran 1, diperoleh hasil perhitungan efektivitas penerimaan pajak Daerah Kota Makassar tahun tahun 2019 dan 2020 sebagaimana pada tabel berikut.

Tabel 2 Besarnya efektivitas penerimaan pajak daerah tahun 2019 dan 2020

\begin{tabular}{|c|c|c|c|c|c|}
\hline \multirow{2}{*}{ Tahun } & $\begin{array}{c}\text { Target Pajak } \\
\text { Daerah (Rp) }\end{array}$ & $\begin{array}{c}\text { Realisasi Pajak } \\
\text { Daerahsampai30 }\end{array}$ & $\begin{array}{c}\text { Efekti } \\
\text { vitas }\end{array}$ & $\begin{array}{c}\text { Realisasi Pajak } \\
\text { Daerah (Rp) }\end{array}$ & $\begin{array}{c}\text { Efekt } \\
\text { ivitas }\end{array}$ \\
\hline
\end{tabular}




\begin{tabular}{|r|r|r|r|r|c|}
\hline & & September (Rp) & $(\%)$ & & $(\%)$ \\
\hline 2019 & 1.315 .000 .000 .000 & $748.753 .891,599$ & 56,94 & 1.062 .789 .856 .614 & 81 \\
\hline 2020 & 809.699 .298 .871 & 610.042 .960 .438 & 75,34 & - & - \\
\hline
\end{tabular}

Sumber: Badan Pendapatan Daerah Kota Makassar tahun 2020 (diolah)

Dari tabel di atas menujukkan bahwa target pajak pada tahun 2019 sebesar Rp 1.315.000.000.000 dengan realisasi sampai 30 September 2019 sebesar Rp 748.753.891,599 dengan tingkat efektivitas pencapaian target 56,94 \% dan pada akhir tahun realisasinya sebesar Rp 1.062.789.856.614 dengan tingkat efektivitas $81 \%$ (kategori cukup efektif), sedangkan target pajak pada tahun 2020 turun menjadi Rp 809.699.298.871 dengan realisasi sampai 30 September 2020 sebesar Rp 610.042.960.438 dengan tingkat efektivitas 75,34 \%. Jadi efektivitas penerimaan pajak sampai 30 September pada tahun 2020 lebih KECIL dari pada tahun 2019.

\section{Dampak Covid-19 terhadap Target Pajak Daerah Kota Makassar}

Covid-19 terjadi pada awal tahun 2020 yang menyebabkan terjadinya pembatasan sosial (social distancing), pembatasan jarak fisik (phisical distancing) bahkan pembatasan sosial berskala besar (PSBB). Pembatasan tersebut mulai terjadi secara bertahap pada bulan Maret 2020 dan berlangsung sampai sekarang. Pembatasan tersebut menyebabkan terjadinya penurunan aktivitas ekonomi seperti pengurangan transaksi jual beli tanah yang dapat menyebabkan menurunnya BPHTB, menurunnya pengguna hotel yang menyebabkan penurunan pajak hotel, penurunan aktivitas hiburan bahkan penutupan tempat-tempat hiburan yang menyebabkan penurunan pajak hiburan, penurunan konsumen restoran yang menyebabkan penurunan pajak restoran, penurunan parkir kendaraan yang menyebabkan penurunan pajak parkir, penurunan promosi/reklame yang menyebabkan menurunnya pajak reklame. Hal ini dapat menyebabkan menurunnya target pajak dan realisasi pajak.

Sehubungan dengan itu, maka dampak dari covid -19 terhadap target pajak dapat dilihat data target penerimaan pajak sebelum terjadi covid-19 yakni tahun 2019 dengan setelah terjadinya covid-19 yakni tahun 2020. Adapun hasil pengolahan data perbandingan target penerimaan pajak tersebut sebagaimana pada tabel berikut ini.

Tabel 3 Perbandingan target penerimaan pajak tahun 2019 dengan tahun 2020

\begin{tabular}{|l|l|r|r|r|r|}
\hline \multirow{2}{*}{ No } & \multirow{2}{*}{ Jenis pajak } & \multicolumn{2}{|c|}{ Target $(\mathrm{Rp})$} & \multicolumn{2}{c|}{ Selisih (Rp ) } \\
\cline { 3 - 6 } & & \multicolumn{1}{|c|}{ Tahun 2019 } & \multicolumn{1}{c|}{ Tahun 2020 } & Jumlah & $\%$ \\
\hline 1 & BPHTB & 330.000 .000 .000 & 205.000 .000 .000 & -125.000 .000 .000 & -38 \\
\hline 2 & PBB - P2 & 215.000 .000 .000 & 134.000 .000 .000 & -81.000 .000 .000 & -38 \\
\hline 3 & Pajak hotel & 135.000 .000 .000 & 72.000 .000 .000 & -63.000 .000 .000 & -47 \\
\hline 4 & Pajak hiburan & 77.000 .000 .000 & 30.000 .000 .000 & -47.000 .000 .000 & -61 \\
\hline 5 & Pajak air bawah tanah & 7.000 .000 .000 & 3.036 .312 .497 & -3.963 .687 .503 & -57 \\
\hline
\end{tabular}




\begin{tabular}{|l|l|r|r|r|r|}
6 & Pajak restoran & 185.000 .000 .000 & 104.637 .986 .374 & -80.362 .013 .626 & -43 \\
\hline 7 & Pajak penerangan jalan & 250.000 .000 .000 & 209.000 .000 .000 & -41.000 .000 .000 & -16 \\
\hline 8 & Pajak parkir & 60.750 .000 .000 & 11.000 .000 .000 & -49.750 .000 .000 & -82 \\
\hline 9 & Pajak mineral bukan logam & 2.000 .000 .000 & 0 & -2.000 .000 .000 & -100 \\
\hline 10 & Pajak sarang burung walet & 250.000 .000 & 25.000 .000 & -225.000 .000 & -90 \\
\hline 11 & Pajak reklame & 53.000 .000 .000 & 41.000 .000 .000 & -12.000 .000 .000 & -23 \\
\hline \multicolumn{2}{c|}{ Total } & 1.315 .000 .000 .000 & 809.699 .298 .871 & -505.300 .701 .129 & -38 \\
\hline
\end{tabular}

Sumber: Badan Pendapatan Daerah Kota Makassar tahun 2020 (diolah)

Dari tabel di atas menunjukkan bahwa total target penerimaan pajak Daerah Kota Makassar 2020 sebesar Rp 809.699.298.871 dan tahun 2019 sebesar Rp 1.315.000.000.000 berarti terjadi penurunan sebesar Rp 505.300.701.129 (-38\%). Semua sumber atau jenis pajak mengalami penurunan dengan persentase penurunan terbesar adalah jenis pajak mineral bukan logam disusul pajak sarang burung walet, pajak parkir, pajak hiburan, pajak air bawah tanah, pajak hotel, pajak restoran, BPHTB, PBB-P2, pajak reklame dan terkecil pajak penerangan jalan. Jadi dampak covid-19 terhadap target penerimaan pajak Daerah Kota Makassar adalah menyebabkan terjadinya penurunan target penerimaan pajak tahun 2020 sebesar -33 $\%$ dari tahun sebelumnya.

\section{Dampak Covid-19 terhadap Realisasi Pajak Daerah Kota Makassar}

Dampak covid-19 terhadap realisasi penerimaan pajak Daerah Kota Makassar dapat dilihat dari data perbandingan realisasi penerimaan pajak Daerah Kota Makassar sebelum dan sesudah covid -19. Data penerimaan pajak tahun 2020 sampai 30 September 2020 sehingga yang dibandingkan adalah data realisasi penerimaan pajak sampai 30 September 2019 dengan sampai 30 September 2020. Adapun hasil pengolahan data perbandingan realisasi penerimaan pajak tersebut sebagaimana pada tabel berikut ini.

Tabel 4 Perbandingan realisasi penerimaan pajak per- 30 September

\begin{tabular}{|l|l|r|r|r|r|}
\hline \multirow{2}{*}{ No } & \multirow{2}{*}{ Jenis pajak } & \multicolumn{2}{c|}{ Realisasi (RP ) } & \multicolumn{2}{c|}{ Selisih ( Rp ) } \\
\cline { 3 - 6 } & & \multicolumn{1}{c|}{ Tahun 2019} & \multicolumn{1}{c|}{ Tahun 2020 } & \multicolumn{1}{c|}{ Jumlah } & \multicolumn{1}{c|}{$\%$} \\
\hline 1 & BPHTB & $134.120 .889,723$ & 117.485 .711 .742 & -16.635 .177 .981 & -12.40 \\
\hline 2 & PBB - P2 & $140.437 .677,002$ & 144.053 .699 .031 & 3.616 .022 .029 & 2.57 \\
\hline 3 & Pajak hotel & $79.953 .473,895$ & 34.410 .476 .734 & -45.542 .997 .161 & -59.96 \\
\hline 4 & Pajak hiburan & $30.448 .418,759$ & 12.488 .254 .483 & -17.960 .164 .276 & -58.99 \\
\hline 5 & Pajak air bawah tanah & $2.633 .356,094$ & 3.106 .969 .508 & 473.613 .414 & 17.99 \\
\hline 6 & Pajak restoran & $150.275 .011,671$ & 97.804 .125 .795 & -52.470 .885 .876 & -34.92 \\
\hline
\end{tabular}


Analisis Pajak Daerah ... (Azis, Semmaila \& Lamo) | 128

\begin{tabular}{|l|l|r|r|r|r|}
\hline 7 & Pajak penerangan jalan & $163.829 .713,409$ & 165.173 .276 .465 & 1.343 .563 .056 & 0.82 \\
\hline 8 & Pajak parkir & $14.626 .399,020$ & 7.282 .017 .568 & -7.344 .381 .452 & -50.21 \\
\hline 9 & Pajak mineral bukan logam & 0 & 0 & 0 & 0 \\
\hline 10 & Pajak sarang burung walet & $18.228,400$ & 15.189 .800 & -3.038 .600 & -16.67 \\
\hline 11 & Pajak reklame & $32.410 .723,626$ & 28.223 .239 .312 & -4.187 .484 .314 & -12.92 \\
\hline \multicolumn{2}{|c|}{ Total } & $\mathbf{7 4 8 . 7 5 3 . 8 9 1 . 5 9 9}$ & $\mathbf{6 1 0 . 0 4 2 . 9 6 0 . 4 3 8}$ & $\mathbf{- 1 3 8 . 7 1 0 . 9 3 1 . 1 6 1}$ & $\mathbf{- 1 8 . 5 3}$ \\
\hline
\end{tabular}

Sumber: Badan Pendapatan Daerah Kota Makassar tahun 2020 (diolah)

Dari Tabel 4 menunjukkan bahwa total realisasi penerimaan pajak Daerah Kota Makassar sampai 30 September 2020 sebesar Rp 610.042.960.438,- dan tahun 2019 sebesar Rp 748.753.891.599,- berarti terjadi penurunan penerimaan pajak sebesar Rp 138.710.931.161 (-18.53\%). Namun demikian dari 11 jenis pajak tersebut ternyata ada 3 jenis pajak yang bahkan mengalami kenaikan yaitu PBB - P2 naik 2.57\%, pajak air bawah tanah naik $17.99 \%$ dan pajak penerangan jalan naik $0.82 \%$.

\section{Pembahasan}

\section{A. Efektivitas Penerimaan Pajak Daerah}

Hasil penelitian ini menunjukkan bahwa tingkat efektivitas pencapaian target pajak sampai 17 Juni 2019 sebesar 28 \% dan pada akhir tahun 2019 sebesar 81 \% kemudian tingkat efektivitas sampai 17 Juni 2020 sebesar $43 \%$. Dari hasil pengolahan data secara kuantitatif menunjukkan bahwa terjadi peningkatan pencapaian efektivitas sampai 17 Juni 2019 ke sampai 17 Juni 2020. Peningkatan ini bukan disebabkan oleh kenaikan realisasi penerimaan pajak karena realisasi yang sesungguhnya justru terjadi penurunan realisasi penerimaan, sehingga peningkatan efektivitas itu disebabkan karena terjadi penurunan target penerimaan pajak di tahun 2020 dimana penurunan tersebut lebih besar dari penurunan realisasi penerimaan pajak.

Pencapaian target tahun 2019 yang hanya 81 \% tidak perlu dilakukan peningkatan pencapaian target ke depan dengan cara menurunkan target tetapi yang utama adalah peningkatan realisasi penerimaan pajak. Penurunan target memang meningkatkan efektivitas tetapi bisa berpengaruh negatif terhadap penurunan motivasi dan aktivitas untuk meningkatkan realisasi penerimaan pajak. Tingkat efektivitas yang hanya $81 \%$ lebih rendah dari rata-rata efektivitas pencapaian target pajak daerah Kota Makassar tahun 2015 (Hasil penelitian Syamsuddin, dkk (2015)).

\section{B. Dampak Covid-19 terhadap Target Pajak Daerah Kota Makassar}

Hasil penelitian ini menunjukkan bahwa terjadi penurunan target penerimaan pajak Daerah Kota Makassar pada tahun 2020. Terjadinya penurunan target tersebut karena pemerintah Kota Makassar sudah memprediksi terjadinya penurunan realisasi penerimaan pajak akibat adanya covid-19. Covid-19 terjadi pada awal tahun 2020 yang menyebabkan terjadinya pembatasan sosial (social distancing), pembatasan jarak fisik (phisical distancing) bahkan pembatasan sosial berskala besar (PSBB). Pembatasan tersebut mulai terjadi secara bertahap pada bulan Maret 2020 dan berlangsung sampai sekarang. Pembatasan tersebut menyebabkan terjadinya 
penurunan aktivitas ekonomi. Hal ini menyebabkan perkiraan terjadinya penurunan total pajak Daerah Kota Makassar. Menurut penulis, dampak covid-19 terhadap target (perkiraan penerimaan) pajak terhadap setiap jenis pajak daerah adalah menurunkan BPHTB, PBB-P2, pajak hotel, pajak hiburan, pajak air bawah tanah, pajak restoran, pajak parkir, pajak sarang burung walet dan pajak reklame tetapi meningkatkan pajak penerangan jalan dan tidak berpengaruh terhadap pajak mineral bukan logam.

Dari data target pajak untuk setiap jenis pajak mengalami penurunan. Semua sumber atau jenis pajak mengalami penurunan dengan persentase penurunan terbesar adalah jenis pajak mineral bukan logam disusul pajak sarang burung walet, pajak parkir, pajak hiburan, pajak air bawah tanah, pajak hotel, pajak restoran, BPHTB, PBB-P2, pajak reklame dan terkecil pajak penerangan jalan. Adapun jastifikasi penulis terhadap target setiap jenis pajak adalah:

a. Target penerimaan BPHTB menurun, menurut penulis adalah benar karena berkurangnya daya beli masyarakat dan berkurangnya keinginan masyarakat untuk melakukan investasi tanah dan bangunan terutama dengan tujuan untuk mendapatkan keuntungan. Hal itu menyebabkan nilai transaksi jual beli tanah dan bangunan menurun sehingga diperkirakan terjadi penurunan transaksi jual beli tanah dan bangunan sehingga target penerimaan BPHTB turun.

b. Target penerimaan PBB naik, menurut penulis dari segi dampak covid-19 adalah tidak berpengaruh terhadap objek PBB tetapi hanya menurunkan kemampuan masyarakat membayar pajak sehingga kemungkinan terjadi sedikit penundaan pembayaran PBB. Covid-19 tidak berpengaruh terhadap penurunan jumlah pajak yang harus dibayar oleh masyarakat. Di sisi lain ternyata ada beberapa nilai NJOP tanah dan bangunan di Kota Makassar yang mengalami peningkatan di tahun 2020. Sebagai contoh adalah PBB tanah dan bangunan milik Syamsuddin di Jl. Perintis Kemerdekaan Km. 9 yang mana terjadi peningkatan PBB yang sangat besar yakni pada tahun 2019 hanya Rp 791.039 naik pada tahun 2020 menjadi Rp 2.370.700, (bukti terlampir). Terjadi kenaikan sebesar $200 \%$. Berdasarkan data tersebut, maka penulis melakukan wawancara dengan Bapak Syamsuddin selaku pemilik tanah tersebut dan sebagai tokoh masyarakat mengenai kenaikan pajak tersebut. Hasil wawancara menunjukkan bahwa memang benar terjadi kenaikan pajak tersebut di atas pada hal bangunannya sudah 11 tahun dan tidak ada penambahan bangunan selama 11 tahun ini. Selanjutnya penulis melakukan pengamatan di lapangan, hasilnya menunjukkan bahwa memang bangunannya sudah lama dan tidak ada penambahan bangunan baru. Selain itu, penulis melakukan wawancara langsung terhadap karyawan bank pembangunan Daerah Sulselbar di Jl. Perintis Kemerdekaan yang menangani setoran PBB mengenai kenaikan PBB yang hasilnya menyatakan bahwa memang yang kami terima ada beberapa objek pajak yang mengalami kenaikan pada tahun 2020 dari tahun 2019 di Makassar.

Sehubungan dengan itu, menurut perkiraan penulis akan terjadi kenaikan penerimaan PBB di tahun2020 sehingga target penerimaan PBB naik. Jadi penulis berpendapat terjadi kekeliruan target PBB 2020 yang turun, idealnya naik.

c. Target penerimaan Pajak hotel menurun, menurut penulis adalah benar karena berkurangnya orang yang menggunakan jasa penginapan dan jasa lainnya di 
hotel. Terjadi penurunan drastis orang yang menginap di hotel, bahkan tidak ada lagi kegiatan pelatihan, seminar dan pesta perkawinan di Hotel. Hal ini menyebabkan penurunan pendapatan hotel sehingga pajaknya juga pasti turun sehingga target penerimaan pajak hotel turun.

d. Target penerimaan Pajak hiburan menurun, menurut penulis adalah benar karena berkurangnya orang yang menggunakan jasa hiburan di rumah karaoke, diskotik, bioskop, pagelaran kesenian, kontes kecantikan dan bina raga, pameran, sirkus dan billiard, putsal. bahkan pada saat lock dawn tempat hiburan ditutup sehingga sama sekali tidak ada pendapatan hiburan sehingga target penerimaan pajak hiburan turun.

e. Target penerimaan air bawah tanah menurun, menurut penulis adalah benar karena berkurangnya penggunaan air di tempat bisnis yang menggunakan air bawah tanah seperti di hotel, restoran, pariwisata. Hal ini menyebabkan penurunan objek pajak air tanah sehingga target penerimaan pajak air bawah tanah turun.

f. Target penerimaan Pajak restoran menurun, menurut penulis adalah benar karena berkurangnya orang yang menggunakan jasa restoran. Selama covid banyak orang takut makan di restoran, di rumah saja makan. Hal ini menyebabkan penurunan pendapatan restoran sehingga pajaknya juga pasti turun sehingga target penerimaan pajak restoran turun.

g. Target penerimaan Pajak penerangan jalan menurun, menurut penulis adalah keliru karena bertambah orang yang tinggal di rumah yang dapat menyebabkan pertambahan penggunaan energi listrik di rumah. Pertambahan itu hanya sedikit. Terjadi penambahan sedikit energi listrik sehingga pajaknya juga naik sedikit sehingga target penerimaan pajak idealnya naik sedikit.

h. Target penerimaan Pajak parkir menurun, menurut penulis adalah benar karena berkurangnya orang yang menggunakan jasa parkir. Terjadi penurunan drastis orang yang memarkir kenderaannya di tempat parkir hotel, gedung tempat pesta, di restoran, tempat hiburan, pertokoan. Hal ini menyebabkan penurunan pendapatan parkir sehingga pajaknya juga pasti turun sehingga target penerimaan pajak parkir turun.

i. Target penerimaan pajak mineral bukan logam menurun bahkan tidak ada, menurut penulis adalah benar tetapi penurunannya bukan karena covid-19. Argumentasinya sudah diuraikan sebelumnya.

j. Target penerimaan Pajak sarang burung walet menurun, menurut penulis adalah benar karena covid-19 berpengaruh negatif terhadap harga sarang burung walet akibat penurunan permintaan dari luar negeri karena pengurangan penerbangan/ekspor.

k. Target penerimaan Pajak reklame menurun, menurut penulis adalah benar karena berkurangnya pengusaha yang mempromosikan produknya (barang atau jasa) melalui Reklame. Aktivitas ekonomi berkurang drastis menyebabkan penurunan pendapatan reklame sehingga pajaknya juga pasti turun sehingga target penerimaan pajak reklame turun.

Hasil penelitian ini menunjukkan bahwa dampak covid-19 berpengaruh negatif terhadap total target pajak daerah kota Makassar tahun 2020 yakni menyebabkan penurunan target pajak tahun 2020. Hasil penelitian ini mendukung pernyataan dalam Hanoatubun, S. (2020), Susilawati, Falefi dan Purwoko (2020) dan Santoso, Y. 
I. (2020). Ibrahim, A., A. (2020) dan Utomo, S. (2020) yang pada intinya menyatakan bahwa dampak covid-19 terhadap perekonomian adalah terjadinya banyak PHK, Kontraksi PMI Manufacturing, banyak penerbangan dibatalkan, kunjungan turis turun dan penurunan occupansi hotel. Hal ini tentunya menurunkan nilai objek pajak daerah sehingga target atau perkiraan penerimaan pajak menurun. Hasil penelitian ini juga mendukung pula pernyataan Direktur Jenderal Pajak Kristiadi, B. B. (2020) yang menunjukkan bahwa covid-19 berpengaruh negatif terhadap berbagai sektor ekonomi menyebabkan penurunan objek pajak sehingga diperkirakan terjadi penurunan penerimaan. Hasil penelitian ini mendukung pula hasil penelitian Silpa Hanoatubun (2020), Burhanuddin, C. I. dan Ardi (2020), Susilawati, Falefi dan Purwoko (2020), Pitaloka, dkk. (2020) dan Feyisa, H. L. (2020) yang menunjukkan bahwa covid-19 berpengaruh negatif terhadap perekonomian Indonesia. Penurunan aktivitas tersebut menyebabkan penurunan objek pajak sehingga diperkirakan terjadi penurunan penerimaan pajak daerah Kota Makassar.

\section{Dampak Covid-19 terhadap Realisasi Pajak Daerah Kota Makassar}

Hasil penelitian ini menunjukkan bahwa terjadi penurunan total realisasi penerimaan pajak Daerah Kota Makassar pada tahun 2020. Menurut jastifikasi penulis adalah benar. Terjadinya penurunan tersebut akibat adanya covid-19. Covid19 terjadi pada awal tahun 2020 yang menyebabkan terjadinya pembatasan sosial (social distancing), pembatasan jarak fisik (phisical distancing) bahkan pembatasan sosial berskala besar (PSBB). Pembatasan tersebut mulai terjadi secara bertahap pada bulan Maret 2020 dan berlangsung sampai sekarang. Jadi penurunan tersebut terjadi mulai bulan Maret 2020.

Adapun jastifikasi penulis terhadap realisasi setiap jenis pajak adalah:

a. Realisasi penerimaan ВРНТВ menurun. Menurut penulis penurunan tersebut akibat dampak negatif dari covid-19. Covid-19 menyebabkan berkurangnya daya beli masyarakat dan berkurangnya keinginan masyarakat untuk melakukan investasi tanah dan bangunan terutama dengan tujuan untuk mendapatkan keuntungan. Hal itu menyebabkan nilai transaksi jual beli tanah dan bangunan menurun sehingga terjadi penurunan transaksi jual beli tanah dan bangunan sehingga realisasi penerimaan BPHTB turun. Jika dikaitkan kenaikan NJOP tanah yang begitu tinggi di tahun 2020 sementara BPHTB menurun menunjukkan bahwa jumlah unit transaksi jual beli tanah dan bangunan mengalami penurunan yang besar.

b. Realisasi penerimaan PBB meningkat sangat besar. Menurut penulis peningkatan tersebut bukan disebabkan oleh covid-19 sebab covid-19 berdampak negatif terhadap penerimaan PBB karena adanya penurunan kemampuan masyarakat menayar PBB yang dapat menyebabkan penundaan pembayaran sehingga menurunkan PBB. Hal ini menunjukkan bahwa ada faktor lain yang menyebabkan peningkatan tersebut. Hasil penelusuran penulis terhadap PBB diperoleh fakta bahwa ternyata ada beberapa nilai NJOP tanah dan bangunan di Kota Makassar yang mengalami peningkatan di tahun 2020. Sebagai contoh adalah PBB tanah dan bangunan milik Syamsuddin di Jl. Perintis Kemerdekaan $\mathrm{Km} .9$ yang mana terjadi peningkatan PBB yang sangat besar yakni pada tahun 2019 hanya Rp 791.039 naik pada tahun 2020 menjadi Rp 2.370.700, (bukti 
terlampir). Terjadi kenaikan sebesar $200 \%$. Hasil wawancara penulis dengan teller bank pembangunan Daerah Sulselbar di Jl. Perintis Kemerdekaan yang menangani setoran PBB menyatakan bahwa memang terjadi beberapa kenaikan objek PBB pada tahun 2020. Jadi peningkatan tersebut disebabkan oleh kenaikan NJOP (nilai jual objek pajak).

c. Realisasi penerimaan Pajak hotel menurun. Menurut penulis penurunan tersebut akibat dampak negatif dari covid-19. Covid-19 menyebabkan berkurangnya orang yang menggunakan jasa penginapan dan jasa lainnya di hotel. Terjadi penurunan drastis orang yang menginap di hotel, bahkan tidak ada lagi kegiatan pelatihan, seminar dan pesta perkawinan di Hotel. Hal ini menyebabkan penurunan pendapatan hotel sehingga pajaknya juga pasti turun sehingga realisasi penerimaan pajak hotel turun.

d. Realisasi penerimaan Pajak hiburan menurun. Menurut penulis penurunan tersebut akibat dampak negatif dari covid-19. Covid-19 menyebabkan berkurangnya orang yang menggunakan jasa hiburan di tempat karaoke, diskotik, tempat pijat, dan tempat keramaian, bahkan pada saat lock down tempat hiburan ditutup sehingga sama sekali tidak ada pendapatan hiburan sehingga realisasi penerimaan pajak hiburan turun.

e. Realisasi penerimaan air bawah tanah naik. Menurut penulis peningkatan tersebut bukan dampak positif dari covid-19. Covid-19 menyebabkan berkurangnya penggunaan air di tempat bisnis yang menggunakan air bawah tanah seperti di hotel, restoran, pariwisata. Hasil penelusuran penulis melalui internet di daerah lain ternyata di daerah lain ada beberapa daerah yang dibebaskan dari pajak air tanah karena dampak covi-19 seperti di Kabupaten Sinjai, Blitar dan Kabupaten Jaya Pura. Hal ini menyebabkan penurunan objek pajak air bawah tanah sehingga idealnya menurun tetapi faktanya realisasi naik. Ini menunjukkan adanya faktor lain yang mempengaruhi kenaikan realisasi pajak air bawah tanah. Penulis telah menelusuri penyebab kenaikan tersebut tetapi tidak ditemukan secara jelas penyebabnya. Penulis menduga kenaikan itu disebabkan oleh adanya peningkatan tunggakan pembayaran pajak air tanah tahun 2019 yang baru dibayar pada tahun 2020.

f. Realisasi penerimaan Pajak restoran menurun. Menurut penulis penurunan tersebut akibat dampak negatif dari covid-19. Covid-19 menyebabkan berkurangnya orang yang menggunakan jasa restoran. Selama covid banyak orang takut makan di restoran, di rumah saja makan. Hal ini menyebabkan penurunan pendapatan restoran sehingga pajaknya juga pasti turun sehingga realisasi penerimaan pajak restoran turun.

g. Realisasi penerimaan Pajak penerangan jalan meningkat. Menurut penulis peningkatan tersebut akibat dampak positif dari covid-19. Covid-19 yakni terjadinya lock down sehingga pada waktu siang berkurang orang yang masuk kantor pada instansi pemerintah dan pemerintah daerah dan bertambah orang yang tinggal di rumah yang dapat menyebabkan pertambahan penggunaan energi listrik di rumah yang kena pajak. Menurut UU RI Nomor 28 tahun 2009 pasal 52 dan sesuai Peraturan Daerah Kota Makassar Nomor 2 Tahun 2018 bahwa objek Pajak Penerangan Jalan adalah penggunaan tenaga listrik, baik yang dihasilkan sendiri maupun yang diperoleh dari sumber lain. Dikecualikan dari objek Pajak Penerangan Jalan tersebut adalah penggunaan tenaga listrik 
oleh instansi Pemerintah dan Pemerintah Daerah. Jadi pegawai yang sebelumnya kerja di kantor tidak bayar pajak menjadi tinggal di rumah bayar pajak. Jadi ada pergeseran dari penggunaan listrik tidak kena pajak menjadi kena pajak. Inilah yang menyebabkan realisasi penerimaan pajak penerangan jalan meningkat.

h. Realisasi penerimaan Pajak parkir menurun. Menurut penulis penurunan tersebut akibat dampak negatif dari covid-19. Covid-19 menyebabkan berkurangnya orang yang menggunakan jasa parkir di tempat parkir yang kena pajak parkir. Terjadi penurunan drastis orang yang memarkir kenderaannya di tempat parkir hotel, gedung tempat pesta, di restoran, tempat hiburan, pertokoan dan pariwisata. Hal ini menyebabkan penurunan pendapatan parkir sehingga pajaknya juga pasti turun sehingga realisasi penerimaan pajak parkir turun.

i. Realisasi penerimaan pajak mineral bukan logam 0 . Tidak pernah ada realisasi penerimaan pajak mineral bukan logam. Menurut penulis tidak adanya sama sekali realisasi pajak mineral bukan logam karena memang pada tahun 2019 dan 2020 sudah tidak ada lagi objek pajak mineral bukan logam yang dapat dikenakan pajak. Jadi tidak ada pengaruh dan covid-19.

j. Realisasi penerimaan Pajak sarang burung walet menurun. Menurut penulis penurunan tersebut akibat dampak negatif dari covid-19. Covid-19 tidak berpengaruh terhadap volume produksi tetapi berpengaruh terhadap harga sarang burung walet. Berdasarkan penelusuran penulis melalui internet seperti KORANKALTIM.COM (12 Februari 2020), TANA TIDUNG (12 Februari 2020), REPUBLIKA.CO.ID. (6 Februari 2020) bahwa Wabah virus Corona menyebabkan terjadinya pengurangan penerbangan dan ekspor ke luar negeri sehingga harga jual barang ekspor termasuk sarang burung walet menurun. Secara teknis, turunnya harga jual sarang burung walet dilatarbelakangi kebijakan pengendalian virus Corona dengan menutup sementara masuknya produk asal hewan dari luar negeri, termasuk Indonesia. Karena pengaruh virus Corona, semua pasar eksportir ke China sedang ditutup.Terkait besaran penurunan harga yang dialami pada Awal Februari ini. Diungkapkan Fazrin bisa mencapai 30 sampai 40 persen. Kondisi ini merata untuk sarang burung walet dari jenis mangkok, sudut dan patahan.". Jadi karena ekspor ke Cina ditutup termasuk ke negara lain seperti Singapura dan Eropa, maka permintaan menurun sementara supply tetap sehingga harga jual menurun. Inilah yang menyebabkan penurunan pajak sarang burung walet.

k. Realisasi penerimaan Pajak reklame menurun. Menurut penulis penurunan tersebut akibat dampak negatif dari covid-19. Covid-19 menyebabkan aktivitas ekonomi menurun sehingga berkurangnya pengusaha yang mempromosikan produknya (barang atau jasa) melalui Reklame sehingga pendapatan jasa reklame menurun sehingga otomatis menyebabkan pajak reklame menurun.

Hasil penelitian ini menunjukkan bahwa dampak covid-19 berpengaruh negatif terhadap total realisasi pajak daerah kota Makassar tahun 2020 yakni menyebabkan penurunan realisasi pajak tahun 2020. Hasil penelitian ini mendukung pernyataan dalam Hanoatubun, S. (2020), Susilawati, Falefi dan Purwoko (2020) dan Santoso, Y. I. (2020). Ibrahim, A., A. (2020) dan Utomo, S. (2020) yang pada intinya menyatakan bahwa dampak covid-19 terhadap perekonomian adalah terjadinya banyak PHK, Kontraksi PMI Manufacturing, banyak penerbangan dibatalkan, kunjungan turis 
turun dan penurunan occupansi hotel. Hal ini tentunya menurunkan nilai objek pajak daerah sehingga realisasi atau perkiraan penerimaan pajak menurun. Hasil penelitian ini juga mendukung pula pernyataan Direktur Jenderal Pajak Kristiadi, B. B. (2020) yang menunjukkan bahwa covid-19 berpengaruh negatif terhadap berbagai sektor ekonomi menyebabkan penurunan objek pajak sehingga diperkirakan terjadi penurunan penerimaan. Hasil penelitian ini mendukung pula hasil penelitian Silpa Hanoatubun (2020), Burhanuddin, C. I. dan Ardi (2020), Susilawati, Falefi dan Purwoko (2020), Pitaloka, dkk. (2020) dan Feyisa, H. L. (2020) yang menunjukkan bahwa covid-19 berpengaruh negatif terhadap perekonomian Indonesia. Penurunan aktivitas tersebut menyebabkan penurunan objek pajak sehingga terjadi penurunan realisasi penerimaan pajak daerah Kota Makassar pada tahun 2020).

\section{KESIMPULAN}

1. Jenis pajak Daerah Kota Makassar yang dipungut sudah sesuai dengan undangundang.dan peraturan Daerah Kota Makassar

2. Jenis pajak yang memberi kontribusi besar terhadap pajak Daerah Kota Makassar adalah pajak penerangan jalan, BPHTB dan pajak restoran serta PBBP2. Jenis pajak yang memberikan kontribusi kecil adalah pajak mineral bukan logam, pajak sarang burung walet dan pajak air bawah tanah.

3. Besarnya efektivitas penerimaan pajak Daerah Kota Makassar per 30 September 2019 sebesar 56.94 \% (cukup efektif) dan per 30 September 2020 sebesar $75.34 \%$. Hal ini dikarenakan penurunan Target PAD disebabkan oleh PAndemi Covid 19 dari Rp.1.315.000.000.000,- menjadi Rp.809.699.298.871,-.

4. Dampak covid-19 terhadap target pajak Daerah Kota Makassar adalah berdampak negatif yakni menurunkan target penerimaan pajak Daerah Kota Makassar.

5. Dampak covid-19 terhadap realisasi pajak Daerah Kota Makassar adalah secara total berdampak negatif terhadap realisasi pajak Daerah Kota Makassar. Namun secara parsial ada yang berdampak positif yaitu realisasi pajak penerangan jalan, selain itu ada yang tidak berdampak yaitu pajak mineral bukan logam.

\section{SARAN}

1. Disarankan kepada pemerintah Kota Makassar terutama BAPENDA Kota Makassar untuk melakukan peninjauan terhadap keberadaan jenis pajak mineral bukan logam dan pajak sarang burung walet dalam perubahan Perda Nomor 2 tahun 2018 yang akan datang. Sebaiknya jenis pajak mineral bukan logam langsung saja dihapus (dihilangkan), sedangkan pajak sarang burung walet masih perlu analisis dan pertimbangan lebih lanjut untuk menetapkan keputusan dihapus atau tetap.

2. Disarankan kepada pemerintah Kota Makassar terutama BAPENDA Kota Makassar untuk menetapkan target penerimaan pajak untuk setiap jenis pajak yang lebih akurat dengan mempertimbangkan dampak covid-19 dan faktorfaktor lain yang bisa berdampak (berpengaruh) terhadap perkiraan penerimaan pajak Daerah Kota Makassar. Perlu dipahami bahwa dampak covid-19 terhadap penerimaan pajak daerah untuk setiap jenis pajak berbeda-beda yakni ada yang 
berdampak positif, berdampak negatif dan ada yang tidak berdampak, besarnya dampak tersebut bervariasi.

3. Selama masih banyak penyebaran covid-19 yang berdampak negatif terhadap kondisi perekonomian, maka disarankan agar tetap ada kebijakan keringanan pembayaran pajak terhadap objek pajak yang terkena dampak negatif dan besar. Jenis pajak yang terkena dampak negatif covid-19 dan besar adalah pajak hotel, pajak hiburan dan pajak restoran.

\section{DAFTAR PUSTAKA}

Arief, A., \& Djanggih, H. (2020). Implementasi Penarikan Retribusi Izin Mendirikan Bangunan Terhadap Realisasi Pendapatan Asli Daerah. Kertha Patrika, 42(1), 73-86

Astuty, P. (2018). Kemandirian Keuangan Daerah: Kebijakan Desentralisasi Fiskal Dan Otonomi Daerah Di Indonesia. JAMAK, 5(2), 1-16.

Kamaroellah, R. A. (2017). Analisis Tingkat Kemampuan Keuangan Daerah dalam Mendukung Pelaksanaan Otonomi Daerah. NUANSA: Jurnal Penelitian Ilmu Sosial dan Keagamaan Islam, 14(1), 123-138.

Mangeswuri, D. R. (2018). Bagian Ketiga Pengelolaan Penerimaan Pendapatan Daerah. Optimalisasi Kebijakan Penerimaan Daerah, 57.

Nasution, A. P. (2019). Strategi Pembangunan Daerah Dalam Meningkatkan Mutu Sumber Daya Alam Dan Sumber Daya Manusia. Jurnal Ebma (Jurnal Ekonomi, Bisnis, Manajemen dan Akuntansi), 1(1), 88-96.

Rahman, A. (2010). Perencanaan dan Pelaksanaan Anggaran Daerah Berbasis Kinerja. Jurnal Ilmu Administrasi: Media Pengembangan Ilmu dan Praktek Administrasi, 7(4), 01.

Ristanti, Y. D., \& Handoyo, E. (2017). Undang-undang otonomi daerah dan pembangunan ekonomi daerah. Jurnal RAK (Riset Akuntansi Keuangan), 2(1), 115-122.

Saragih, A. H. (2018). Pengaruh Penerimaan Pajak Terhadap Pertumbuhan Ekonomi di Indonesia. Jurnal Sikap, 3(1), 277683.

Sidik, M. (2002). Perimbangan keuangan pusat dan daerah sebagai pelaksanaan desentralisasi fiskal. In Makalah Seminar Setahun Implementasi Kebijakan Otonomi Daerah.

Syamsudin, S., Cahya, B. T., \& Dewi, S. N. (2015). Pengaruh Kinerja Keuangan terhadap Pertumbuhan Ekonomi, Pengangguran dan Kemiskinan. Jurnal Manajemen Dayasaing, 17(1), 15-27.

Wijayanti, S. N. (2017). Hubungan Antara Pusat dan Daerah Dalam Negara Kesatuan Republik Indonesia Berdasarkan Undang-Undang Nomor 23 Tahun 2014. Jurnal Media Hukum, 23(2), 186-199. 
Analisis Pajak Daerah ... (Azis, Semmaila \& Lamo) | 136

Winarno, B. (2004). Implementasi Konsep Reinventing Government Dalam Pelaksanaan Otonomi Daerah. Dialogue: Jurnal Ilmu Administrasi Dan Kebijakan Publik, 1(2), 1-24. 